\title{
Referral to cancer genetic counseling: do migrant status and patients' educational background matter?
}

\author{
J. A. M. van der Giessen ${ }^{1}$ - E. van Riel $^{1}$ - M. E. Velthuizen ${ }^{1}$ - A. M. van Dulmen ${ }^{2,3,4}$. \\ M. G. E. M. Ausems 1
}

Received: 19 May 2017 / Accepted: 21 August 2017 /Published online: 4 September 2017

(C) The Author(s) 2017. This article is an open access publication

\begin{abstract}
Participation rates in cancer genetic counseling differ among populations, as patients with a lower educational background and migrant patients seem to have poorer access to it. We conducted a study to determine the present-day educational level and migrant status of counselees referred to cancer genetic counseling. We assessed personal characteristics and demographics of 731 newly referred counselees. Descriptive statistics were used to describe these characteristics. The results show that about $40 \%$ of the counselees had a high educational level and $89 \%$ were Dutch natives. Compared to the Dutch population, we found a significant difference in educational level $(p=<0.01)$ and migrant status $(p=<0.001)$. This suggests disparities in cancer genetic counseling and as a result of that, suboptimal care for vulnerable groups. Limited health literacy is likely to pose a particular challenge to cancer genetic counseling for counselees
\end{abstract}

This article is part of the Topical Collection on Inclusion of Diverse Populations In Genomics Research and Health Services: A Scientific and Health Equity Imperative

Electronic supplementary material The online version of this article (https://doi.org/10.1007/s12687-017-0326-4) contains supplementary material, which is available to authorized users.

M. G. E. M. Ausems

M.G.E.M.Ausems@umcutrecht.nl

1 Department of Genetics, Division of Biomedical Genetics, University Medical Center Utrecht, PO Box 85090, Utrecht 3508 $\mathrm{AB}$, The Netherlands

2 NIVEL (Netherlands Institute for Health Services Research), Utrecht, The Netherlands

3 Department of Primary and Community Care, Radboud University Medical Center, Nijmegen, the Netherlands

4 Faculty of Health Sciences, University College of Southeast Norway, Drammen, Norway with a lower education or a migrant background. Our study points to considerable scope for improvement in referring vulnerable groups of patients for cancer genetic counseling.

Keywords Cancer genetic counseling $\cdot$ Referral $\cdot$ Migrant status $\cdot$ Educational level

\section{Introduction}

For families in which a hereditary form of cancer is suspected, cancer genetic counseling can add to the optimal treatment and clinical management of patients. It can serve as a valuable aid for surveillance and/or preventive surgery for patients affected by cancer and their unaffected family members. Therefore, identifying patients eligible for cancer genetic counseling and referring them is important. Unfortunately, due to various physician- and patient-related factors (Brandt et al. 2008), not all patients eligible for genetic counseling are recognized by their physicians (Kurian et al. 2017).

\section{Physician-related factors}

From physicians' perspective, patient eligibility for cancer genetic counseling is based on family history, patient cancer history, and patient request (Brandt et al. 2008). The first challenge for physicians is to identify patients eligible for referral by gathering adequate information about the family history. As shown, EMRs (electronic medical records) do not always contain enough information about family history (Sollie et al. 2016; Vogel et al. 2012). Vogel et al. (2012) found that only $50 \%$ of the patients who are eligible for referral for Lynch syndrome and hereditary breast and ovarian cancer could be identified by the EMR. Current standard clinical practices 
seem insufficient at identifying patients who meet the criteria for referral to genetic counseling.

The majority of physicians experience a lack of time to collect detailed information about family history (Al-Habsi et al. 2008; Wood et al. 2008). Insufficient knowledge about hereditary cancer and about the criteria for referral acts as another barrier for referral (Dekker et al. 2013; Panic et al. 2014). Besides, physicians tend to overestimate the risk of patients who actually are at population risk, while underestimating risk of patients who are at increased risk of developing cancer (Baldwin et al. 2014). Despite the fact that referral guidelines are sufficiently available, numerous studies have shown that physicians are still lacking knowledge of genetics and the latest criteria for referral (Douma et al. 2016; Prochniak et al. 2012).

When physicians are convinced, there is a high probability that the risk is hereditary; they have a tendency to refer patients for periodic screening examinations instead of genetic counseling (Burke et al. 2009; Sollie et al. 2016). For colorectal cancer syndromes, Prochniak et al. (2012) found that, although physicians endorsed guidelines as a significant influence on their practice decisions, these guidelines did not influence the referral to cancer genetic counseling. The low adherence to guidelines for referral and poor registration of family history may also be responsible for the differences in referral to cancer genetic counseling in migrant patients. In a study among Turkish and Moroccan patients by Baars et al. (2016), the lowest referral rates are observed in the group of women with breast cancer at young age, despite the fact that age $<40$ years is a criterion for referral, independent of family history and migrant status (Baars et al. 2016).

\section{Patient-related factors}

Patient characteristics influence the referral process as well. Patients' request for cancer genetic counseling and their concerns about family members are important determinants for cancer genetic counseling. Van Riel et al. (2012) showed that the majority of counselees initiate a referral themselves (van Riel et al. 2012), while Brandt et al. (2008) found that $73 \%$ of a group of primary care physicians and specialists base patient eligibility for referral on patient request, and 54\% did not refer eligible patients due to patient disinterest. When physicians are not sure whether screening is recommended, patients who expect screening and those who are more anxious, are more often referred (Haggerty et al. 2005). Apparently, cancer-related concerns, but also perceived cancer risk and the belief that family history influences cancer risk, contribute to referral for cancer genetic counseling (Bellcross et al. 2015).

Lack of awareness and/or knowledge about personal risk, medical history, and genetic services, seem to act as barriers to referral to cancer genetic counseling (Delikurt et al. 2015). Research from Allford et al. (2014) suggests low awareness and understanding of familial cancer risk among minority ethnic communities (Allford et al. 2014). Also, socio-cultural variations in beliefs, notably stigma about cancer of inherited risk of cancer, have been identified. For migrant breast cancer patients, language difficulties and lower health literacy, as well as cultural factors, are determinants for nonparticipation in genetic counseling (Baars et al. 2017).

Sharing information with the physician about family history in relation to cancer, is an important factor in the referral process. Patients with a lower social economic status, a lower educational background, or a migrant background, experience greater verbal passivity and difficulties in presenting healthrelated information to their physician (Cooper and Roter, 2003).

\section{Differences in cancer incidence}

Cancer incidence may vary in the population and therefore result in different participation rates in cancer genetic counseling. Migrants and people of low socioeconomic status (SES) share certain cancer risks, like the lower risks for colon, skin, breast, and prostate cancer (Aarts et al. 2010; Arnold et al. 2010). Nonwestern migrants exhibit a higher burden of infection-related tumors (Arnold et al. 2010; Dutch Cancer Society 2006; Visser and van Leeuwen, 2007). The difference in cancer incidence in the population is complex, because higher cancer awareness and participation in cancer screening programs, might have contributed to a higher incidence for certain types of cancer, like breast cancer. This is usually promoted more by patients of high SES (Aarts et al. 2010). Recent research from Welch and Fisher (2017) confirms that cancer screening is one area in which overutilization can result in overdiagnosis, particularly for cancers for which the reported incidence is sensitive to early screening programs (Welch and Fisher, 2017). Reported higher incidence does not seem to lead to a parallel increase in prevalence, as shown by the database from the National Institute of Public Health and the Environment (RIVM). This database showed no significant difference in prevalence of cancer between the lowest and highest educated people (National Institute for Public Health and the Environment 2012).

\section{Cancer genetic counseling}

In order to gain more insight in factors associated with referral to genetic counseling, we conducted an observational study in 2007 (van Riel et al. 2012). That study showed that, compared to the general population, more highly educated counselees and less migrant counselees were seen in cancer genetic counseling practice.

Since 2007, more information has become available about hereditary cancer and referral for cancer genetic counseling. 
For physicians, guidelines have been updated and published about criteria for referral (Balmana et al. 2013; Berliner et al. 2013; Giardiello et al. 2014). Also, additional value of interventions, such as an online referral test, an interactive web- based training and an electronic referral form, has been reported (Bell et al. 2015; Dekker et al. 2014; Petzel et al. 2014).

For the general public, attention to this subject has been drawn in the media, e.g., by the release of a public statement

Table 1 General characteristics of 731 counselees requesting cancer genetic counseling

\begin{tabular}{|c|c|c|c|c|c|}
\hline Variable & & $\begin{array}{l}\text { Both clinics combined } \% \\
(n=731)\end{array}$ & $\begin{array}{l}\text { University hospital \% } \\
(n=403)^{\mathrm{a}}\end{array}$ & $\begin{array}{l}\text { Community hospitals } \% \\
(n=328)^{\mathrm{a}}\end{array}$ & $\begin{array}{l}p \\
\text { value }\end{array}$ \\
\hline \multicolumn{2}{|l|}{ Total } & 100.0 & 55.1 & 44.9 & \\
\hline Gender & $\begin{array}{l}\text { Male } \\
\text { Female }\end{array}$ & $\begin{array}{l}25.6(187) \\
74.4(544)\end{array}$ & $\begin{array}{l}26.6(107) \\
73.4(296)\end{array}$ & $\begin{array}{l}24.4(80) \\
75.6(248)\end{array}$ & n.s. \\
\hline Personal cancer history & $\begin{array}{l}\text { Affected } \\
\text { Unaffected }\end{array}$ & $\begin{array}{l}50.8(371) \\
49.2(360)\end{array}$ & $\begin{array}{l}46.7(188) \\
53.3(215)\end{array}$ & $\begin{array}{l}55.8(183) \\
44.2(145)\end{array}$ & $0.014 *$ \\
\hline \multirow[t]{8}{*}{ Affected with $(n=371)$} & Breast cancer & $56.3(209)$ & $60.6(114)$ & $51.9(95)$ & n.s. \\
\hline & Ovarian cancer & $4.0(15)$ & $2.7(5)$ & $5.5(10)$ & n.s. \\
\hline & Colon cancer & $16.4(61)$ & $10.1(19)$ & $23.0(42)$ & $0.001 *$ \\
\hline & Endometrial cancer & $0.8(3)$ & $1.6(3)$ & $0(0)$ & n.s. \\
\hline & Melanoma & $2.7(10)$ & $4.3(8)$ & $1.1(2)$ & n.s. \\
\hline & Polyposis & $9.2(34)$ & $9.6(18)$ & $8.7(16)$ & n.s. \\
\hline & $\geq 2$ kinds of cancer & $5.1(19)$ & $5.3(10)$ & $4.9(9)$ & n.s. \\
\hline & Other ${ }^{\mathrm{b}}$ & $5.4(20)$ & $5.9(11)$ & $4.9(9)$ & n.s. \\
\hline \multirow[t]{5}{*}{$\begin{array}{l}\text { Eligibility for genetic testing in } \\
\text { counselee or relative }\end{array}$} & $\begin{array}{l}\text { Diagnostic DNA } \\
\text { testing }\end{array}$ & $38.2(279)$ & $36.0(145)$ & $40.9(134)$ & n.s. \\
\hline & $\mathrm{MSI} / \mathrm{IHC}^{\mathrm{c}}$ & $11.6(85)$ & $9.4(38)$ & $14.3(47)$ & $0.040 *$ \\
\hline & Predictive testing ${ }^{\mathrm{d}}$ & $22.0(161)$ & 29.5 (119) & $12.8(42)$ & $0.000 *$ \\
\hline & $\begin{array}{l}\text { Did not meet criteria } \\
\text { for testing }\end{array}$ & $10.4(76)$ & $8.7(35)$ & $12.5(41)$ & n.s. \\
\hline & Other & $17.8(130)$ & $16.4(66)$ & $19.5(64)$ & n.s. \\
\hline \multirow{3}{*}{$\begin{array}{l}\text { Initiator discussing family history } \\
(n=707)\end{array}$} & Counselee & $35.6(252)$ & $38.3(148)$ & $32.4(104)$ & n.s. \\
\hline & Physician & $48.4(342)$ & $42.2(163)$ & $55.8(179)$ & $0.000 *$ \\
\hline & Other & $16.0(113)$ & $19.4(75)$ & $11.8(38)$ & $0.006^{*}$ \\
\hline \multirow[t]{4}{*}{ Educational level $^{\mathrm{e}}(n=714)$} & Low & $5.0(36)$ & $4.1(16)$ & $6.2(20)$ & n.s. \\
\hline & Intermediate-1 & $21.6(154)$ & $18.7(73)$ & $25.1(81)$ & $0.038 *$ \\
\hline & Intermediate-2 & $35.2(251)$ & $31.7(124)$ & $39.3(127)$ & $0.034^{*}$ \\
\hline & High & $38.2(273)$ & $45.5(178)$ & $29.4(95)$ & $0.000 *$ \\
\hline \multirow[t]{3}{*}{$\operatorname{Migrant}_{\text {status }}{ }^{\mathrm{f}}(n=723)$} & $\begin{array}{l}\text { Dutch native } \\
\text { Migrant }\end{array}$ & $\begin{array}{l}88.7(641) \\
11.3(82)\end{array}$ & $\begin{array}{l}86.6(342) \\
13.4(53)\end{array}$ & $\begin{array}{l}91.2(299) \\
8.8(29)\end{array}$ & $0.053 *$ \\
\hline & Migrant, western & $6.7(49)$ & $7.1(28)$ & $6.4(21)$ & n.s. \\
\hline & Migrant, non-western & $4.6(33)$ & $6.3(25)$ & $2.4(8)$ & $0.013^{*}$ \\
\hline
\end{tabular}

* A two-sided $p$ value of $<0.05$ is considered significant. n.s.: not significant

${ }^{a}$ Data calculated for clinical setting (i.e., within each column)

${ }^{\mathrm{b}}$ Other cancer: parathyroid adenoma, angiolipoma, carcinoid, brain tumor, hyperparathyroidism, pituitary tumor, leiomyomatosis, leukemia, neurofibroma, kidney cancer, pancreatic cancer, prostate cancer, sarcoma, sebaceoma, esophageal cancer, and testis carcinoma

${ }^{\mathrm{c}} \mathrm{MSI} / \mathrm{IHC}$ : microsatellite instability testing/immunohistochemistry for mismatch repair deficiency

${ }^{\mathrm{d}}$ Predictive testing: genetic testing for a mutation which is already known in the family of the counselee

${ }^{\mathrm{e}}$ Low: (pre-)primary education or first stage of basic education; Intermediate-1: lower secondary or second stage of basic education; Intermediate-2: (upper) secondary education; High: tertiary education

${ }^{\mathrm{f}}$ Dutch native: both parents are born in The Netherlands; Migrant: at least one of the parents is born outside the Netherlands. Western Migrant: at least one parent born outside the Netherlands, but in Europe, North America, Australia, New Zealand, Indonesia, and Japan; Non-Western Migrant: at least one parent born in Turkey and countries in Africa, Latin America, and Asian countries 
Table 2 Educational level and migrant status of counselees in cancer genetic counseling in comparison to the general population in the Netherlands

\begin{tabular}{lccc}
\hline & This study $(2014 / 2015) \%(n)$ & General population $(2014) \%(n)$ & $p$ value \\
\hline Educational level & & & $<0.01$ \\
Low & $5.0(36)$ & $9.8(1,229,000)$ & 0.7033 \\
Intermediate-1 & $21.6(154)$ & $21.0(2,625,000)$ & $<0.01$ \\
Intermediate-2 & $35.2(251)$ & $40.7(508,900)$ & $<0.01$ \\
High & $38.2(273)$ & $28.5(3,564,000)$ & $<0.001$ \\
Migrant status & & & \\
Dutch native & $88.7(641)$ & $78.6(13,234,545)$ & \\
Migrant & $11.3(82)$ & $21.4(3,594,744)$ & \\
- Western & $6.8(49)$ & $9.5(1,597,160)$ & \\
- non-Western & $4.6(33)$ & $11.9(1,997,584)$ & \\
\hline
\end{tabular}

from actress Angelina Jolie (Evans et al. 2014; Roberts and Dusetzina, 2017).

Over the years, for both physicians as the general population, awareness about cancer genetic counseling has increased. This is expected to be reflected in a cancer genetic counseling population which is more comparable to the general population when it comes to educational level and migrant status. To study this expectation, we conducted a study, 8 years after our previous study, with the aim to determine the present-day educational level and migrant status of counselees referred to cancer genetic counseling and to investigate possible differences with our 2007 data.

\section{Methods}

\section{Participants}

Participants were newly referred counselees for cancer genetic counseling from October 2014 to April 2015. Similar to our previous study (van Riel et al. 2012), counselees were seen by a clinical geneticist or genetic counselor from the department of Genetics of the University Medical Center Utrecht at either the university main site or one of the nine community hospitals in the region.

\section{Study design and data collection}

For each new counselee, a checklist was filled in by the counselor during the first consultation. In this checklist, several items were scored: general characteristics of the counselee and the consultation, eligibility for genetic testing, educational level, country of birth of counselee and his/her parents (see Electronic Supplementary Material).

Educational level was determined by the Dutch Standard Classification of Education (Statistics Netherlands 2008) and the international classification of the UNESCO (Unesco Institute for Statistics 2011): low educational level: (pre-)primary education or first stage of basic education; intermediate1 educational level: lower secondary or second stage of basic education; intermediate-2 educational level: (upper) secondary education; and high educational level: tertiary education.

Migrant status of the counselee was determined according to the definition of Statistics Netherlands (Statistics Netherlands 2008). According to this definition, a counselee is a migrant when at least one of the parents is born outside of the Netherlands. Furthermore, a distinction can be made between Western migrants (at least one parent born outside the Netherlands, but in Europe, North America, Australia, New Zealand, Indonesia, and Japan) and non-Western migrants (at least one parent born in Turkey and countries in Africa, Latin America, and Asian countries). The classifications of
Table 3 Educational level and migrant status of counselees in cancer genetic counseling in comparison to the study in 2007 (Van Riel et al. 2012)

\begin{tabular}{llll}
\hline & This study $(2014 / 2015) \%(n)$ & Study data $(2007) \%(n)$ & $p$ value \\
\hline Educational level & & & \\
Low & $5.0(36)$ & $4.0(16)$ & 0.4340 \\
Intermediate-1 & $21.6(154)$ & $26.3(105)$ & 0.0723 \\
Intermediate-2 & $35.2(251)$ & $33.3(133)$ & 0.5400 \\
High & $38.2(273)$ & $36.3(145)$ & 0.5314 \\
Migrant status & & & \\
Dutch native & $88.7(641)$ & $90.6(368)$ & 0.2998 \\
Migrant & $11.3(82)$ & $9.4(38)$ & \\
\hline
\end{tabular}


educational level and migrant status of Statistics Netherlands was chosen to allow comparison with data about the general population of the Netherlands. Also, these same classifications were used in our earlier study (van Riel et al. 2012), so, comparison with the data of the current study with the situation in 2007 is possible.

Eligibility for genetic testing was determined for the counselee or for an affected family member of the counselee based on family history and/or (if available at initial consultation) medical records, according to national guidelines for different tumor syndromes used in daily practice.

The subgroup "other" in eligibility for genetic testing contains several reasons, e.g., eligibility can be determined after receiving the medical records of the counselee and/or family members, which are not always present at first consultation. Also, in initiating discussion of family history, a category "other" exists. This category contains initiating discussion of family history by a family member, by a family letter (a letter in case a mutation in a cancer gene is detected, intended to share with family), by the counselee and physician together, or by the physician of a family member.

\section{Statistical analysis}

All data were entered in SPSS Version 21.0.0. Descriptive statistics were used to describe counselee characteristics, for university and community hospitals separately, and for both clinics combined. Chi-square tests were used to compare the collected data to the data of the general population in the Netherlands (Statistics Netherlands 2014a; Statistics Netherlands 2014b).

\section{Results}

\section{General characteristics}

In total, 731 counselees were included. General characteristics, like clinical setting of the consultation, gender and personal cancer history of the counselee, and eligibility for genetic testing are shown in Table 1 . There were more female counselees compared to male counselees, as more than half $(56 \%)$ of the affected counselees had breast cancer. About half of all counselees were seen in the university hospital (55\%); the other $45 \%$ were seen in community hospitals. This is the same distribution as reported earlier in our study in 2007 (van Riel et al. 2012).

When we compare the referral between university hospital and community hospitals, we found that more counselees affected with colon cancer were seen in community hospitals, which explains the higher eligibility for microsatellite instability testing/immune histochemistry (MSI/IHC) of counselees seen in community hospitals. In the university hospital, more counselees were seen for predictive testing for a known mutation.

In initiating discussion of family history, we found discussion started by a family member in $58 \%$, by a family letter in $23 \%$, by the counselee and physician together in $14 \%$, and by the physician of a family member in $5 \%$. In community hospitals, the physician more often initiated discussion of family history, and less often, this discussion is initiated by "other" (e.g., a family member or via a family letter).

\section{Educational level}

When classified according to the International Standard Classification of Education (Unesco Institute for Statistics 2011), about $40 \%$ of the counselees seen for cancer genetic counseling had a high educational level. When compared for clinical setting, more counselees with an intermediate- 1 and intermediate- 2 level of education were seen in community hospitals, and more highly educated counselees were seen in the university hospital. In comparison with the Dutch population (Table 2), less counselees with a lower and intermediate-2 educational level and more highly educated counselees were seen in cancer genetic counseling. No significant difference was found in the educational level of counselees in 2007 and in 2014/2015 (van Riel et al. 2012) (Table 3).

\section{Migrant status}

The majority of counselees seen for cancer genetic counseling were Dutch natives $(89 \%)$. There is a trend for less migrants seen in the community hospitals $(p=0.05)$. When migrants of Western and non-Western origin were compared, a significantly lower percentage of non-Western migrants is seen in community hospitals than in the university hospital. Furthermore, there were less migrants seen in cancer genetic counseling compared to the general population (Table 2) $(p<0.001)$. We found no significant difference in frequency of migrants referred for cancer genetic counseling 2014/2015 and 2007 (van Riel et al. 2012), (Table 3).

\section{Discussion}

Our findings suggest that patients' migrant status and educational background seem to matter in the referral to cancer genetic counseling. In 2007, we found an underrepresentation in cancer genetic counseling of migrant patients and patients with a low educational background (van Riel et al. 2012). The results of the current study show that this underrepresentation has not changed since then. This differential access to cancer genetic counseling may lead to treatment and outcome disparities in cancer care. 
The differences in educational level and migrant status, seen between counselees in the university hospital and counselees seen in the community hospital, must be taken into account. However, definite conclusions cannot be drawn from these data because of potential differences in the patient population at the different locations. Socio demographic characteristics may have impact on patients' communicative behavior (e.g., asking questions or expressing concerns) as well on physicians' behavior (discussing referral possibility) (Baars et al. 2017).

In the last years, more information about cancer genetics and genetic counseling has become accessible to the general public. From popular magazines, there is an increasing focus on hereditary cancer and referral for DNA-testing. This may affect people's awareness for cancer genetic counseling and may even contribute to more patient request. As we know, patients' initiative is important in the referral process (Brandt et al. 2008; Wideroff et al. 2003). Asking questions about genetic testing increases the likelihood of being referred for genetic counseling (Al-Habsi et al. 2008; Klitzman et al. 2013). This might be an explanation for the relatively low attendance of migrant patients and patients with a lower educational background. Asking questions is associated with someone's health literacy skills (Katz et al. 2007). Health literacy skills reflect the ability to access, understand, appraise, and use health-related information in various domains (Sorensen et al. 2012) and are associated with lower patient activation (Smith et al. 2013). People with a lower socioeconomic position, a lower educational level, and a lower subjective social status, are known to have lower health literacy skills than those with a high socio-economic position (Heide van der et al. 2013). Also, many migrant patients have lower health literacy skills (Fransen et al. 2013). This might result in low awareness or understanding of familial cancer. In combination with socio-cultural variations in beliefs about cancer, this may affect patient-doctor communication, as well as referral to cancer genetic counseling (Baars et al. 2017). Given the fact that the majority of counselees seem to initiate referral to genetic counseling themselves (Brandt et al. 2008; van Riel et al. 2012), lower health literacy and corresponding lower patient activation, might contribute to the lower referral rate in migrant patients and in patients with a lower level of education. Physicians will have to adapt their communication to this group of patients in order to allow effective communication and get a higher referral rate. Recent research (Kurian et al. 2017) emphasizes the importance of oncologists' behavior in the genetic testing process. Improving their communication skills and risk estimation and optimizing triage to genetic counselors have priority.

Lower educated counselees may have other needs for genetic care than higher educated counselees (Hayat et al. 2012), who argue for a more personalized approach in both the referral process and in the genetic counseling itself. Culturesensitive interventions can ameliorate referral to cancer genetic counseling (Hall and Olopade, 2006). Our study points to room for improvement in referring vulnerable groups of patients. Since the outcome of cancer genetic counseling can give reasons to choose another treatment procedure, this is even more important (Christinat and Pagani, 2013; Glenn et al. 2012; Wevers et al. 2012). Limited health literacy is likely to pose a particular challenge to cancer genetic counseling for counselees with a lower education or a migrant background. Future studies can explore how physicians should assess patients' need and skills and which communication strategies are effective.

\section{Limitations}

Our findings cannot be generalized as the study was conducted in one single clinical genetic center. However, we included a rather large number of counselees (over 700 consecutive counselees seen for cancer genetic counseling) who were seen in several hospitals in the central region of the Netherlands. Due to the study design, we do not have data about counselees who declined referral for cancer genetic counseling. These possible decliners may have had a different educational background. Also, we did not measure the level of health literacy of the patients, but considered educational background as a proxy (Heide van der et al. 2013; Martin et al. 2009). Numerous studies show the importance of patient request or initiative in the referral process. However, in our study, we found no association between initiative of the counselee and participation in cancer genetic counseling. That is probably because of bias in the scoring procedure. Although we asked who took the initiative for referral, we realize that this outcome is fairly unreliable. It is not always clear who took the initiative and sometimes the respondents did not even remember.

The observed difference in referral between university and community hospitals might be influenced by the approach of our genetic clinic: When a pathogenic mutation is identified in the index case, he/she receives a family letter to inform family members. With this letter, family members can directly contact our department at the university hospital, and are more often invited for a consultation at this location. Furthermore, more information about characteristics of the referring physicians and their practice might lead to a better clarification of the differences seen between consultations in the different clinical settings.

As cancer incidence, as well as demographics of the Dutch population, vary over years, this may influence the referral for cancer genetic counseling. In our study, we did not standardize for these differences. Related to migrant status and socioeconomic inequalities, a variety of studies from Europe has shown that disparities in the burden of cancer exist (Arnold 
et al. 2010). In further research, we must take these differences into account.

To conclude, the results in this study are similar to the results in 2007. Lower participation in cancer genetic counseling by migrant patients and patients with a lower educational background is still a cause for concern. Additional research on interventions on how to improve referral for these patients is urgently desired.

Acknowledgements We thank all clinical geneticists and genetic counselors for their contribution and for completing the checklist.

\section{Compliance with ethical standards}

Conflict of interest The authors declare that they have no conflict of interest.

Ethical approval All procedures followed were in accordance with the ethical standards of the responsible clinic. For this study, no ethical approval was required, because most items of the checklist are discussed routinely in regular consultations. We did not ask the counselees to perform any action, like filling out questionnaires.

Open Access This article is distributed under the terms of the Creative Commons Attribution 4.0 International License (http:// creativecommons.org/licenses/by/4.0/), which permits unrestricted use, distribution, and reproduction in any medium, provided you give appropriate credit to the original author(s) and the source, provide a link to the Creative Commons license, and indicate if changes were made.

\section{References}

Aarts MJ, vander AAMA, Coebergh JW, Louwman WJ (2010) Reduction of socioeconomic inequality in cancer incidence in the south of the Netherlands during 1996-2008. Eur J Cancer 46(14): 2633-2646

Al-Habsi H, Lim JN, Chu CE, Hewison J (2008) Factors influencing the referrals in primary care of asymptomatic patients with a family history of cancer. Genet Med 10(10):751-757

Allford A, Qureshi N, Barwell J, Lewis C, Kai J (2014) What hinders minority ethnic access to cancer genetics services and what may help? Eur J Hum Genet 22(7):866-874

Arnold M, Razum O, Coebergh JW (2010) Cancer risk diversity in nonwestern migrants to Europe: an overview of the literature. Eur J Cancer 46(14):2647-2659

Baars JE, van Dulmen AM, Velthuizen ME, Theunissen EB, Vrouenraets BC, Kimmings AN, van DT, van OB, Witkamp AJ, van der AAMA, Ausems MG (2016) Migrant breast cancer patients and their participation in genetic counseling: results from a registry-based study. Familial Cancer 15(2):163-171

Baars JE, van Dulmen AM, Velthuizen ME, van Riel E, Ausems MG (2017) Breast cancer genetic counseling among Dutch patients from Turkish and Moroccan descent: participation determinants and perspectives of patients and healthcare professionals. J Community Genet 8(2):97-108

Baldwin LM, Trivers KF, Andrilla CH, Matthews B, Miller JW, Lishner DM, Goff BA (2014) Accuracy of ovarian and colon cancer risk assessments by U.S. physicians. J. Gen. Intern. Med 29(5):741-749
Balmana J, Balaguer F, Cervantes A, Arnold D (2013) Familial riskcolorectal cancer: ESMO Clinical Practice Guidelines. Ann. Oncol 24(Suppl 6):vi73-vi80

Bell RA, McDermott H, Fancher TL, Green MJ, Day FC, Wilkes MS (2015) Impact of a randomized controlled educational trial to improve physician practice behaviors around screening for inherited breast cancer. J Gen Intern Med 30(3):334-341

Bellcross CA, Peipins LA, McCarty FA, Rodriguez JL, Hawkins NA, Hensley Alford S, Leadbetter S (2015) Characteristics associated with genetic counseling referral and BRCA $1 / 2$ testing among women in a large integrated health system. Genet Med 17(1):43-50

Berliner JL, Fay AM, Cummings SA, Burnett B, Tillmanns T (2013) NSGC practice guideline: risk assessment and genetic counseling for hereditary breast and ovarian cancer. J Genet Couns 22(2):155-163

Brandt R, Ali Z, Sabel A, McHugh T, Gilman P (2008) Cancer genetics evaluation: barriers to and improvements for referral. Genet Test 12(1):9-12

Burke W, Culver J, Pinsky L, Hall S, Reynolds SE, Yasui Y, Press N (2009) Genetic assessment of breast cancer risk in primary care practice. Am J Med Genet A 149A(3):349-356

Christinat A, Pagani O (2013) Practical aspects of genetic counseling in breast cancer: lights and shadows. Breast 22(4):375-382

Cooper LA, Roter DL (2003) Patient-provider communication: the effect of race and ethnicity on process and outcomes of healthcare. In: Smedley BD, Stith AY, Nelson AR (eds) unequal treatment: confronting racial and ethnic disparities in health care. National Academies Press (US), Baltimore, Maryland

Dekker N, Hermens RP, Mensenkamp AR, van Zelst-Stams WA, Hoogerbrugge N (2014) Easy-to-use online referral test detects most patients with a high familial risk of colorectal cancer. Color Dis 16(1):O26-O34

Dekker N, Hermens RP, Nagengast FM, van Zelst-Stams WA, Hoogerbrugge N (2013) Familial colorectal cancer risk assessment needs improvement for more effective cancer prevention in relatives. Color Dis 15(4):e175-e185

Delikurt T, Williamson GR, Anastasiadou V, Skirton H (2015) A systematic review of factors that act as barriers to patient referral to genetic services. Eur J Hum Genet 23(6):739-745

Douma KF, Smets EM, Allain DC (2016) Non-genetic health professionals' attitude towards, knowledge of and skills in discussing and ordering genetic testing for hereditary cancer. Familial Cancer 15(2):341-350

Dutch Cancer Society (2006). Allochtonen en kanker. Sociaal-culturele en epidemiologische aspecten. From https://www.kwf.nl Accessed $17-7-2017$

Evans DG, Barwell J, Eccles DM, Collins A, Izatt L, Jacobs C, Donaldson A, Brady AF, Cuthbert A, Harrison R, Thomas S, Howell A, Miedzybrodzka Z, Murray A (2014) The Angelina Jolie effect: how high celebrity profile can have a major impact on provision of cancer related services. Breast Cancer Res 16(5):442

Fransen M, Harris VC, Essink-Bot ML (2013) Low health literacy in ethnic minority patients: understandable language is the beginning of good healthcare. Ned. Tijdschr. Geneeskd 157(14):A5581

Giardiello FM, Allen JI, Axilbund JE, Boland CR, Burke CA, Burt RW, Church JM, Dominitz JA, Johnson DA, Kaltenbach T, Levin TR, Lieberman DA, Robertson DJ, Syngal S, Rex DK (2014) Guidelines on genetic evaluation and management of Lynch syndrome: a consensus statement by the US Multi-Society Task Force on Colorectal Cancer. Am J Gastroenterol 109(8):1159-1179

Glenn BA, Chawla N, Bastani R (2012) Barriers to genetic testing for breast cancer risk among ethnic minority women: an exploratory study. Ethn Dis 22(3):267-273

Haggerty J, Tudiver F, Brown JB, Herbert C, Ciampi A, Guibert R (2005) Patients' anxiety and expectations: how they influence family physicians' decisions to order cancer screening tests. Can Fam Physician 51:1658-1659 
Hall MJ, Olopade OI (2006) Disparities in genetic testing: thinking outside the BRCA box. J Clin Oncol 24(14):2197-2203

Hayat RA, Lampic C, Ingvoldstad C, Askmalm MS, Bjorvatn C, Rosenquist R, Nordin K (2012) What information do cancer genetic counselees prioritize? J Genet Couns 21(4):510-526

Heide van der I, Rademakers J, Schipper M, Droomers M, Sorensen K, Uiters E (2013) Health literacy of Dutch adults: a cross sectional survey. BMC Public Health 13:179

Katz MG, Jacobson TA, Veledar E, Kripalani S (2007) Patient literacy and question-asking behavior during the medical encounter: a mixed-methods analysis. J Gen Intern Med 22(6):782-786

Klitzman R, Chung W, Marder K, Shanmugham A, Chin LJ, Stark M, Leu CS, Appelbaum PS (2013) Attitudes and practices among internists concerning genetic testing. J Genet Couns 22(1):90-100

Kurian AW, Griffith KA, Hamilton AS, Ward KC, Morrow M, Katz SJ, Jagsi R (2017) Genetic testing and counseling among patients with newly diagnosed breast cancer. JAMA 317(5):531-534

Martin LT, Ruder T, Escarce JJ, Ghosh-Dastidar B, Sherman D, Elliott M, Bird CE, Fremont A, Gasper C, Culbert A, Lurie N (2009) Developing predictive models of health literacy. J Gen Intern Med 24(11):1211-1216

National Institute for Public Health and the Environment (2012). Kanker naar opleidingsniveau en geslacht. From https://www. volksgezondheidenzorg.info Accessed 17-07-2017

Panic N, Leoncini E, Di GP, Simone B, Silenzi A, Ferriero AM, Falvo R, Silvestrini G, Cadeddu C, Marzuillo C, De VC, Ricciardi W, Villari P, Boccia S (2014) Survey on knowledge, attitudes, and training needs of Italian residents on genetic tests for hereditary breast and colorectal cancer. Biomed Res Int 2014:418416

Petzel SV, Vogel RI, McNiel J, Leininger A, Argenta PA, Geller MA (2014) Improving referral for genetic risk assessment in ovarian cancer using an electronic medical record system. Int J Gynecol Cancer 24(6):1003-1009

Prochniak CF, Martin LJ, Miller EM, Knapke SC (2012) Barriers to and motivations for physician referral of patients to cancer genetics clinics. J Genet Couns 21(2):305-325

Roberts MC, Dusetzina SB (2017) The effect of a celebrity health disclosure on demand for health care: trends in BRCA testing and subsequent health services use. J Community Genet 8(2):141-146

Smith SG, Curtis LM, Wardle J, von WC, Wolf MS (2013) Skill set or mind set? Associations between health literacy, patient activation and health. PLoS. One 8(9):e74373
Sollie A, Helsper CW, Ader RJ, Ausems MG, van der Wouden JC, Numans ME (2016) Primary care management of women with breast cancer-related concerns-a dynamic cohort study using a network database. Eur. J. Cancer Care (Engl. ) 25(6):1005-1014

Sorensen K, Van den Broucke S, Fullam J, Doyle G, Pelikan J, Slonska Z, Brand H (2012) Health literacy and public health: a systematic review and integration of definitions and models. BMC Public Health 12:80

Statistics Netherlands (2008). The Dutch Standard Classification of Education, SOI 2006. From https://www.cbs.nl Accessed 17-72017

Statistics Netherlands (2014a). Bevolking; generatie, geslacht, leeftijd en herkomstgroepering. From http://statline.cbs.nl Accessed 17-72017

Statistics Netherlands (2014b). Bevolking; hoogst behaald onderwijsniveau; geslacht, leeftijd en herkomst From http:// statline.cbs.nl Accessed 17-7-2017

Unesco Institute for Statistics (2011). International Standard Classification of Education. From http://uis.unesco.org Accessed $17-7-2017$

van Riel E, van Dulmen S, Ausems MG (2012) Who is being referred to cancer genetic counseling? Characteristics of counselees and their referral. J Community Genet 3(4):265-274

Visser O, van Leeuwen FE (2007) Cancer risk in first generation migrants in North-Holland/Flevoland, The Netherlands, 1995-2004. Eur J Cancer 43(5):901-908

Vogel TJ, Stoops K, Bennett RL, Miller M, Swisher EM (2012) A selfadministered family history questionnaire improves identification of women who warrant referral to genetic counseling for hereditary cancer risk. Gynecol Oncol 125(3):693-698

Welch HG, Fisher ES (2017) Income and cancer overdiagnosis - when too much care is harmful. N Engl J Med 376(23):2208-2209

Wevers MR, Hahn DE, Verhoef S, Bolhaar MD, Ausems MG, Aaronson NK, Bleiker EM (2012) Breast cancer genetic counseling after diagnosis but before treatment: a pilot study on treatment consequences and psychological impact. Patient Educ Couns 89(1):89-95

Wideroff L, Freedman AN, Olson L, Klabunde CN, Davis W, Srinath KP, Croyle RT, Ballard-Barbash R (2003) Physician use of genetic testing for cancer susceptibility: results of a national survey. Cancer Epidemiol Biomarkers Prev 12(4):295-303

Wood ME, Stockdale A, Flynn BS (2008) Interviews with primary care physicians regarding taking and interpreting the cancer family history. Fam Pract 25(5):334-340 